Michael Sommer

\title{
Choices - The Use of Textual Authorities in the Revelation of John
}

This article addresses one of the most vibrant areas of current research on the Book of Revelation, the question of the biblical book's intended meaning and audience, by exploring the text's intertextuality. I shall particularly focus on the issue of John's audience and examine if his choice of textual authorities tells us something about his addressees and his enemies. I also challenge the frequently voiced assumption that the Book of Revelation is an anti-Roman writing. A look at John's intertexts supports the scholarly opinion of Tobias Nicklas and Stefan Alkier, who both believe that John's main enemy is not the Roman Empire, but Christians that neglect his claim of authority. ${ }^{1}$ Nevertheless, it is also my purpose to introduce to the literary characteristics of Revelation.

\section{Introduction}

The biblical book of Revelation was written probably at the end of the first or at the beginning of the second century by an author who introduces himself as John. While imprisoned on the island of Patmos (Rev. 1:9), he receives a revelation of Jesus (Rev. 1:1) instructing him to write seven letters to the churches of Asia Minor in order to command them to repent and to change their religious and social behavior. Although chapters 2-3 emphasise that John addresses seven "Christian" communities in Asia Minor, his book is intended for a larger circle of readers. The text itself is a kind of a mosaic of intertextual references to the prophetic writings of the Old Testament. John creates a story by combining allusions particularly to the visions of Ezekiel, Isaiah and Daniel. He even imitates larger structural outlines of the Old Testament prophets. Looking at the history of research on John's Apocalypse, it is clear that John's intertextuality was not only one of the key topics scholars focused on since the early 1960s, but that how scholars read John's intertexts caused them to interpret the message of John completely differently. The way they looked at the intertextuality of the book clearly influenced the pictures they drew of John as an author, of the addressees of the book and of John's adversaries.

One might even go further: even if methods of reading and defining phenomena like text and intertext have progressed in the last 50 years, the heritage of scholarly trends from the late 1960s is still visible in modern intertextual research on the

\footnotetext{
1 See Alkier, "Schwerwiegende Differenzen.”

ว Open Access. (C) 2020 Michael Sommer, published by De Gruyter. (ख) BY-Nc-ND This work is licensed under the Creative Commons Attribution-NonCommercial-NoDerivatives 4.0 License.

https://doi.org/10.1515/10.1515/9783110597745-006
} 
Revelation of John. ${ }^{2}$ The most recent publication on John's use of scriptures, the presidential address of the Colloquium Biblicum Lovaniense in 2015, ${ }^{3}$ pointed out that the debate on the Book of Revelation's use of scriptures is still very schematic. In Adela Yarbro Collins' eyes, opinions about Revelation's role and function among early Christians in Asia Minor have changed substantially in the last twenty years, but intertextual approaches have not kept pace with these scholarly developments. The different standpoints and research questions in the debate on John's intertexts (which text form of the Old Testament did John use? Did he quote from memory? Did he respect the context of his intertexts?) have not moved far from their beginnings in the 1960 s. ${ }^{4}$ In a recent survey of current developments in the scholarship on Revelation, Thomas Hieke comes to a similar conclusion. According to him, intertextual research runs the risk of repeating older questions. ${ }^{5}$

\section{The Book of Revelation as a Mosaic of Misspelled Texts or John the Literate Illiterate?}

Nearly every introduction to the New Testament draws similar conclusions: John's work is totally dependent on Israel's holy texts, and his language is highly influenced by the works of the prophets and by the psalms. ${ }^{6}$ Whereas texts such as the Ascensio of Isaiah, Apocalypse of Abraham, Apocalypse of Peter, 2 Baruch or 4 Ezra allude extensively to the texts which we attribute to the Old Testament canon, however, the intertextuality of Revelation differs tremendously from them. Even if the reception technique of 5 Ezra has some similarities, John's use of scriptures is to a certain degree more extensive. ${ }^{7}$

\footnotetext{
2 The mechanistic approach of the 1960s was aimed only at identifying all quotations and allusions in the Book of Revelation. Since the late 1980s, scholars have used intertextual relations in order to reconstruct the social milieu of the book. In the 1990s, research focused mainly on the question if modern readers need to know John's intertexts in order to comprehend the message of the book. 3 Yarbro Collins, "The Use of Scripture in Revelation."

4 I am also going to demonstrate that the current opinions on scriptures and authority emerged or derived from different directions of reading developed in the 1960s and sophisticated in the 1980s. 5 See Hieke, "Literarische und theologische Funktion des Alten Testaments." The article is based on a paper Hieke gave at a conference in Frankfurt in 2012. The discussion afterwards clearly pointed out that intertextual research on the Book of Revelation is less innovative than other parts of apocalypse research. I would go so far to say that it represents a single-track or unilinear field of research. See also Yarbro Collins, "Rewritten Prophets."

6 See Witetschek, "Der Lieblingspsalm des Sehers;" Moyise, "The Psalms in the Book of Revelation."

7 Hirschberger tries to unfold the intertextual clustering in 5 Ezra in her monograph.
} 
The Revelation of John is a kind of mosaic. ${ }^{8}$ It is a network composed of a whole variety of different intertexts. John mingled allusions to the prophets, the psalms, and the Torah together and formed a new text out of them. ${ }^{9}$ However, his literary technique of reception is particularly striking. He does not quote texts explicitly. Even if some of his allusions come close to what we would call a quotation, he does not introduce them as such. ${ }^{10}$ Although he does not quote intertexts, he heavily relies on them, and large parts of Revelation imitate the structure of the prophetic writings of Ezekiel and Daniel, which will be discussed in more detail later.

These peculiarities caused scholars in the early 1960s to ask specific questions that have been discussed in numerous articles. Researchers wanted to know, firstly, whether John based himself on the Greek or Hebrew text of the Old Testament writings. Secondly, did he work with written sources or from memory? And finally, did he intermingle different texts on purpose or accidentally? From the 1960s onwards, scholars have produced two different types of answers to these questions, depending on their reading of Revelation. Researchers who compared John's book with only one single intertext have concluded that he received authorial texts intentionally and faithfully. ${ }^{11}$ By contrast, scholars reading Revelation as a mosaic of combined and intermingled intertexts have portrayed John's methods in a completely different way. In their eyes, John "quoted" from memory without having recourse to the written sources. These scholars argued that this accounted for John's allusions to the scriptures differing from the language of the original context. ${ }^{12}$

These two reading patterns rooted in the 1960s still furnish the foundation on which current perspectives on the role of scriptures in John's work are based. Although questions and methods of research progressed over the years, these two perspectives remained enormously influential, and are still present in research today. Their survival is especially noticeable in various studies dating to the late 1980s and early 1990s. ${ }^{13}$ Scholars such as Jeffrey Vogelgesang, ${ }^{14}$ G.K. Beale ${ }^{15}$ or Jay Casey ${ }^{16}$

8 Kowalski, Die Rezeption des Propheten Ezechiel, 496 discusses the term mosaic. See also Frey, “Bildersprache der Johannesapokalypse,” esp. 174.

9 See Fekkes, Isaiah and Prophetic Traditions in the Book of Revelation, 284.

10 Furthermore, John's use of Greek is peculiar. It seems that he purposefully violated nearly every rule of grammar. As a result, scholars for a long time considered John as nearly illiterate whose mother tongue could not possibly have been Greek. However, in the last twenty years younger scholars have shown that Revelation's language is the product of an artificial construction that aims to imitate a Semitic language; probably Hebrew, because it was the language of the cult and the scriptures. For more detailed information, see Moyise, The Old Testament in the Book of Revelation.

11 See Vanhoye, “L'utilisation du Livre d'Ezechiel dans L'Apocalypse.”

12 Vos, The Synoptic Traditions in the Apocalypse. Cf. also Caird, A Commentary on the Revelation of

St. John Divine, 25.

13 See Sommer, 'Tag der Plagen,' 2-4.

14 Vogelgesang, "The Interpretation of Ezekiel in the Book of Revelation."

15 Beale, The Use of Daniel in Jewish Apocalyptic Literature and in Revelation of St. John.

16 Casey, "Exodus Typology in the Book of Revelation." 
compared Revelation to only one single text, to the Book of Ezekiel, the Book of Daniel and Exodus respectively. They each assumed that their chosen text had been the most important template for the literary outline of the Book of Revelation, and argued that it therefore offered the key to John's theology. According to this position, John was an author who carefully read intertexts and played with their original meaning. He was comprehensively aware of the content of his intertexts. It was his intention to create a narrative reminiscent of the prophets' in order to claim their authority for his own message. According to this position, he used intertexts purposefully and wanted his readers to compare his book with the particular intertexts to which he alluded. The researchers following this line of argument accordingly posited that John's intended audience was familiar with the Hebrew scriptures. Without such knowledge, John's work could not be understood. Therefore the way in which scholars read the intertextuality of the Revelation of John led them to portray his audience as Jewish.

Jean-Pierre Ruiz, however, approached Revelation differently. Also active in the early 1990s, he treated the book as a blend of texts and accordingly reasoned that none of John's intertexts is important on its own. In Ruiz's opinion, readers do not have to have one particular intertext in mind because Revelation's actual message can be understood without a deep knowledge of the scriptures. ${ }^{17}$ He explained why John put together so many different texts by using an argument originally formulated by Louis Vos in the 1960s, who had also emphasised Revelation's literary characteristics as a textual mosaic. In Vos' and Ruiz's eyes, John borrowed the language of the prophets to appropriate their claims to authority for his text. ${ }^{18}$ The author was not interested in one single intertext, but tried to imitate the linguistics and semantics of prophetic texts in order to remind his readers of the authoritative status of this kind of language. ${ }^{19}$ Vos' ideas found wide acceptance in the scholarly community and remained prominent even as new methods entered the scholarly debate. In the 1990s, as reader-response theories and new forms of intertextuality were introduced into apocalypse research, the core of Vos' and Ruiz's thesis was adopted by many scholars, as can be seen in the works of Steve Moyise, Thomas Hieke, and Beate Kowalski, with only marginal variations. ${ }^{20}$

17 See Ruiz, Ezekiel in the Apocalypse, 179. Further Schüssler-Fiorenza, The Book of Revelation, 135. 18 See Ruiz, Ezekiel in the Apocalypse, 533. Further Vos, The Synoptic Traditions in the Apocalypse, 51.

19 See Schüssler-Fiorenza, The Book of Revelation, 135.

20 See Moyise, The Old Testament in the Book of Revelation, 78; Hieke, "Der Seher Johannes als neuer Ezechiel," esp. 29; Kowalski, Die Rezeption des Propheten Ezechiel, 499-500. Synchronic approaches no longer ask if it is important to know John's intertexts, they require it implicitly. For instance, Moyise, Hieke and Kowalski described Revelation's implicit author as someone who wanted to appear as a new Ezekiel or a new Daniel having the same authorial state. Canonical approaches even went so far as to say that the authority of John's book gives the reader the authority to re-read Ezekiel or Daniel in the light of the book of Revelation. 
Reader-response criticism and production-orientated forms of intertextual research share a similar idea of how the intended reader of the Revelation must have looked. Both work with the notion of a reader who lives in the world of scriptures and believes in their authority. The main point of difference between them concerns the question of whether the reader has to know a particular intertext very well or not. Scholars following these approaches, however, mostly ignored the substantial changes in scholarly perspectives on John's audience that have taken place in the meantime.

\section{John's Addressees in the History of Research}

Thoughts about John's views of his political and social environment, of his enemies and of addressees have changed dramatically over the last 50 years. Scholars in the late 1950s and 1960s mostly had a simplistic view of John's audience and his enemies. They read Revelation as a book giving consolation to the Roman Empire's oppressed and persecuted Christians, even though the text mentions neither the emperor nor the Roman Empire by name. ${ }^{21}$ In this phase of research, many scholars saw Revelation's main purpose as one of comfort and support for persecuted Christians by preaching the message of a sovereign god who will punish the evil Roman persecutors at the end of time, while faithful Christians would be rewarded. Although not all scholars followed this position, this was certainly a way of reading the Revelation of John that found many adherents in the mid-twentieth century. Even though remnants of this view are still discernible in recent publications, ${ }^{22}$ historical research has made two discoveries that led to a turning point in this regard:

1. Historians have revised their picture of the emperor Domitian (A.D. 81-96) and now question whether there was a systematic persecution of Christians before Decius. Scholars in the late 70s and early 80s like Adela Yarbro Collins and Elisabeth Schüssler-Fiorenza started to read the idea of crisis in John's narrative as his own purposeful over-interpretation of reality. In their view, John did not simply report a real catastrophe, but exaggerated the danger to the Christian faithful in order to make his call for repentance even more powerful. ${ }^{23}$ Scholars now no longer read Revelation as a book of consolation, but as a warning, even a threat. According to this line of argument, John wanted to frighten his

21 Giesen's oeuvre is a very clear example for the survival of this point of view. In Giesen's view, John's main enemy is the Roman Empire and he wants to force his addressees to resist against the political pressure to worship the Emperor as god. See Giesen, Christlicher Glaube in Anfechtung und Bewährung; Giesen, "Das Römische Reich im Spiegel der Johannes-Apokalypse."

22 Viljoen, "Faithful Christian Living amidst Scoffers of the Judgment Day;" Lichtenberger, Die Apokalypse, 49.

23 See the overview of Witulski, Johannesoffenbarung und Kaiser Hadrian, 72-81. 
Christian audience in order to cause them to isolate themselves from the GrecoRoman culture. This opinion still remains dominant in modern apocalypse research. ${ }^{24}$ Most articles from the 1980 s onwards treat Revelation as a text that opposes Greco-Roman influences on the culture of Asia Minor, and in particular as an aggressive response to the Imperial Cult. Stefan Alkier, however, has recently criticised this viewpoint by making a couple of striking points. He admits, of course, that John's book has a political dimension, ${ }^{25}$ but in his eyes this is just one aspect of John's message. ${ }^{26}$ Alkier argues "that numerous other constellations of conflicts are present throughout John's Apocalypse that are of no little importance to the text's rhetoric and theology."27

2. By the end of the twentieth century, models of diversity established within the field of humanities had an enormous impact on New Testament studies and influenced ideas of the birth of early Christianity. ${ }^{28}$ Scholars have begun to realise more and more that early Christianity was a complex phenomenon of many coexisting ideas and strands that varied in their Christology, theology, ethics and, of course, their scriptural hermeneutics. ${ }^{29}$ This emerging trend can also be seen in apocalypse research and has led to a more cautious interpretation of John's communication with his readers. Scholars no longer read John's letters to the Seven Churches in Asia Minor (Revelation 2-3) ${ }^{30}$ as a simple interface between John and his readers, but as a testimony to early Christian diversity. ${ }^{31}$ Indeed, the letters to the Seven Churches reveal a multitude of different forms of Christian identities. Alkier goes so far as to say that Revelation 2-3 gives insight into a complex struggle between various groups whose profiles can be distinguished. The letters to Smyrna and to Philadelphia mention Jews who are in John's eyes not Jewish, but liars. Scholars have interpreted this passage as reflecting either a local conflict between John and the synagogue, or tensions between John and those Christians who performed some of the Jewish cultic

24 Frey, "Autorfiktion und Gegnerbild im Judasbrief;" Also Kelhofer, Persecution, Persuasion and Power, 159. See also Ameling, Kleinasiatische Kaiserkult und die Öffentlichkeit.

25 A more detailed analysis of John's adversaries is provided by Müller, "Die Tiefen des Satans erkennen...”

26 See Alkier, "Schwerwiegende Differenzen."

27 Alkier, "Schwerwiegende Differenzen,” 3: “[...] dass sich durch die Johannesapokalypse vielfältige andere Konfliktkonstellationen ziehen, die für die Rhetorik und Theologie der Apokalypse keineswegs von minderer Bedeutung sind.”

28 A good overview is provided by Nicklas, Jews and Christians?

29 See, for instance, Lieu, Neither Jew nor Greek.

30 John delivers to them a message from the messiah who criticises the communities' behaviour and calls them to repentance. The whole apocalyptic main part and its visions could be read as a literary radicalisation of this imperative. More detailed Ulland, Die Vision als Radikalisierung der Wirklichkeit in der Apokalypse des Johannes.

31 See Nicklas, "Diesseits aus der Sicht des Jenseits." 
practices. $^{32}$ The letters to Ephesus, to Pergamum ${ }^{33}$ and to Thyatira mention false apostles and false prophets, who, according to John, are spreading heresies in the communities. In John's view, some churches have even accepted the message of those preachers who spread evil teachings. The letters to Sardes and to Laodicea reveal internal tensions within these communities. The messages to Pergamum, to Thyatira and to Laodicea indicate that some of these Churches' members worshiped foreign gods and took part in diverse cults. The writings to Ephesus and to Pergamum indicate local conflicts with the Romans. Scholars associated the Nicolaitans, Balaam and Isebel with Christian groups that overinterpreted the letters of Paul. Paul had a tolerant view on eating idol meat (1 Cor. 8:1.4.7.10; 10:19.28), and the apostle argued that Christians should strive to co-exist more or less harmoniously with non-Christians. ${ }^{34}$ On the contrary, John argued that the consumption of idol meat is an offense against the will of God. Although I cannot portray the whole debate, it seems plausible to me, as it does to Rita Müller-Frieberg, that John's text is responding to pseudo-Pauline teachings, which spread in Asia Minor at the end of the first century. ${ }^{35}$

In any case, the conception of a reader of Revelation who is familiar only with the Hebrew Scriptures and reads these texts as authorial and inspired expressions of the will of God clearly cannot accommodate the obvious diversity of addressees as proposed by modern apocalypse research. The multitude of different perspectives of Christians indicated in Revelation 2-3 surely included very varying interpretations of the scriptures; the latter certainly meant something different to Christians following Jewish cult laws than they did to those who read pseudo-Pauline literature that claimed that the Torah was irrelevant to salvation. In my eyes, Christians who tried to integrate into the Greco-Roman society in order to live a peaceful life as citizens must have interpreted the scriptures politically in a different manner than those Christians who followed John's imperative to keep themselves away from cults and idol meat.

\footnotetext{
32 See Nicklas, "Diesseits aus der Sicht des Jenseits," 263. He also provides a history of research. 33 More detailed, but with an emphasis on the imperial cult, Klauck, "Kaiserkult in der Johannesoffenbarung."

34 See the controversy between Karrer, "Die Apokalypse und das Aposteldekret," and MüllerFrieberg, "Paulusrezeption in der Offenbarung des Johannes."

35 See Sommer, "Nikolaiten und die Gegnerfiktion in der Offenbarung des Johannes."
} 


\section{John's Choice of Intertexts and his Profile of Identity}

In the last part of this essay, I argue that John's choice of intertexts reflects these different layers of communication apparent in Revelation 2-3 and the diversity of his addresses. If one respects the diversity of John's addressees, one has to consider Revelation's intertextuality as being more complex. It is not sufficient to think that Revelation was read only by readers who had in-depth knowledge of Israel's holy texts. On the contrary, one has to consider that each of them might have practiced different hermeneutics.

\subsection{John the Real Jew, Jewish Christians and the Synagogue of Satan}

In the chapter(s) in which John tried to convince Jewish Christians to abandon their ties to synagogues (Rev. 2:9 and 3:9), it is only logical that he expresses his own theological and Christological idea using Jewish traditions. In my eyes, John believes that his idea of Christian identity is the only correct way to fulfill the will of God expressed in the scriptures of Israel.

Richard Hays analyzed the vision of the Son of Man in Revelation 1 and concluded that in this passage, the authority of the intertexts is crucial to understanding the idea of Christ it expresses. ${ }^{36}$ John's way of connecting prophetic ideas of God to the Messiah are unique and cannot be compared with other Christological conceptions from the late first or early second centuries. Moreover, the picture of God in Revelation is influenced more by Jewish textual authorities than by other early Christian texts. John's tour of God's throne room is full of allusions to Ezekiel's Merkabah vision and to Isaiah 6. Even those passages that reveal the hope for the universal salvation of humankind, like Revelation 7, 14 and 21 to 22, strongly rely on motifs from the Hebrew Scriptures. It is also not surprising that John refers to Exodus 19 and the covenant when he speaks about the inner core of Christian communities (Rev. 1; 5; 20). According to him, the Christians he addresses belong to the (hi)story of Israel and its god as told by the Torah and the prophets. It is very clear that John's thoughts were undoubtedly rooted in Jewish religious traditions. His whole book is very Jewish in character.

Nevertheless, one has to ask which aims he pursued in using the scriptures in this way. Did he intend to oppose local synagogues? Did he want to integrate Christians who still went to the synagogue into his community or was it his goal to re-

36 See Hays, "Faithful Witness, Alpha and Omega,” esp. 81. 
place (established) Jewish forms of identity by creating a new Jewish identity of his own? I think the truth may lie somewhere in-between.

\subsection{Opposition against Groups Rejecting the Torah and/or Over- Interpreting Paul}

In my view Revelation's so-called catalogues of vices reflect a conflict between John and the Christians who rejected the laws of the Torah. These catalogues (Rev. 9:20$21 ; 21: 8.27 ; 22: 15)$ are a central part of John's ethics. For the first time in the text, in Revelation 9:20-21 keywords (esp. metanoe,w; Rev. 2:5.16.21.22; 3:3.19; 9:20.21; 16:9.11) appear that refer directly back from the main part of Revelation (Rev. 4-22) to the ethical imperatives of the letters to the Churches (Rev. 2-3). This intratextual connection serves to explain the call for repentance in Revelation 2-3 in greater detail. In these catalogues, readers discover what is required in order to keep their relationship to God intact. Where the main part of the Revelation (Rev. 4-22) merely commands that one stay away from Satan, his evil spirits and from Babylon, ${ }^{37}$ the words of the catalogues of vices are more outspoken. They allude to the Torah and represent a collection of different laws with the Decalogue at its centre. ${ }^{38}$

Tab. 1: Catalogues of vices

\begin{tabular}{|c|c|c|c|}
\hline Revelation 9:20-21 & Revelation 21:8 & Revelation 21:27 & Revelation 22:15 \\
\hline 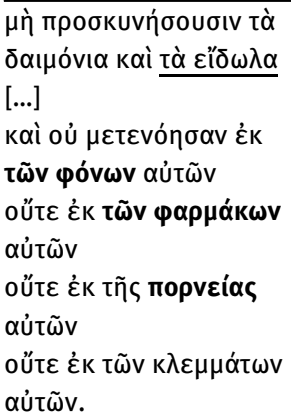 & 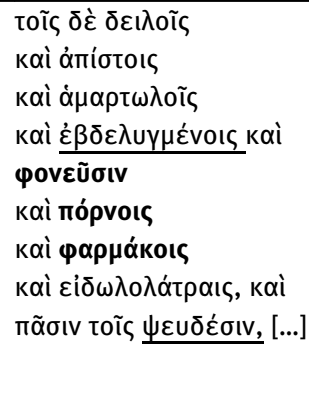 & 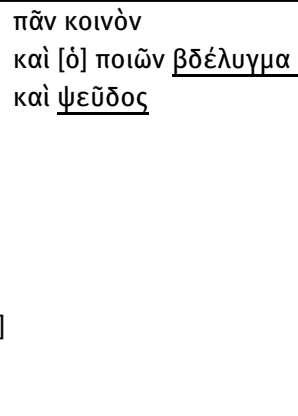 & 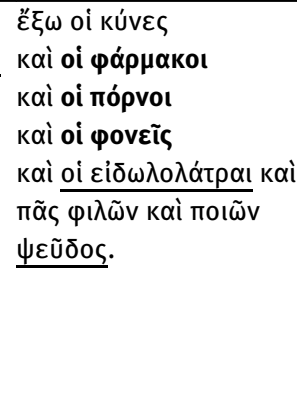 \\
\hline
\end{tabular}

37 Of course, this could be read as an implicit call for demarcation from Greco-Roman society, but this message is covered up with vivid and colourful apocalyptic motifs. See Dochhorn, Schriftgelehrte Prophetie, $101 \mathrm{ff}$.

38 My interpretation differs from Giesen, “Kaiserkult in der Offenbarung des Johannes." See my explanation in Sommer, "Bund, Tora und eklektizistische Identitätsbildung." 


\begin{tabular}{|c|c|}
\hline Worship of demons & Deut. 32:17 \\
\hline Idolatry & $\begin{array}{l}\text { Exod. 20:4; Lev. 19:4; 26:30; Num. 25:2; 33:52; } \\
\text { Deut. 5:8; 29:16; 32:21 }\end{array}$ \\
\hline including a description of material & Lev. 19:4; 33:52; Deut. 29:16 \\
\hline Murder & Exod. 20:1; Deut. 5.18 \\
\hline Sorcery & Exod. 22:17; Deut. 18:10 \\
\hline (Sacral) Prostitution & Deut. 23:18 \\
\hline Thievery & Exod. 20:14; 21:37; 22:3; Lev. 19:11; Deut. 5:19 \\
\hline Disbelief & Generally against Exod. 20:3-5 // Deut. 5 \\
\hline Cowardice & Deut. $20: 8$ \\
\hline 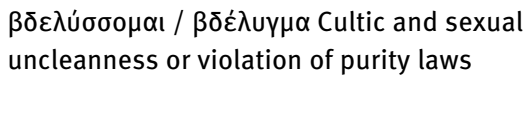 & $\begin{array}{l}\text { Lev. } 5: 2 ; 7: 21 ; 11: 10.11 .12 .13 .20 .23 .41 .42 ; 13: 15 ; \\
14: 3 ; 18: 22.26 .27 .29 .30 ; 20: 13.23 .25 ; \\
\text { Deut. } 7: 25.26 ; 12: 31\end{array}$ \\
\hline
\end{tabular}

These clear connections (indicated in the table by bold print and underlinings) cannot be coincidental. In these key passages, John emphasises very clearly that the laws of the Torah, or at least of parts of it, are still valid. He is using the language of cultic purity laws to express that the heavenly cult is pure and that its performance does not breach those laws of the Torah not superceded by Christ's teaching. He also emphasises that the Torah is not only a collection of ethical commandments, but also expresses how God wants to be adored. John formulates polemics against foreign cults by referring to the deuteronomic prohibition against worshipping demons and to the commandment of the Decalogue not to produce idols.

\subsection{Opposition against Christian Groups Integrating into Greco- Roman Society}

John accuses some Christians in the communities he addresses of assimilating too much to Greco-Roman society. The social and religious structure of Asia Minor was highly complex in the late first and early second centuries. The emperor cult was only one of many different cults that characterised the religious landscape of the province. In the cities, many cults co-existed. ${ }^{39}$ Without going into detail, John argues against those of his addressees who took part in these cults. He expresses his anger that these people ignored his instructions and thus also denied his claim to authority. However, his harsh message of demarcation was difficult to accept for Christians who took part in the everyday life of the cities and the cults of Asia Minor. A closer examination of the catalogues of vices reveals John's attitude towards Christians taking part in Greco-Roman cults: In Revelation 9:20-21; 2:8 and 22:15, John alludes heavily to the laws of the Torah prohibiting idolatry (Exod. 20:4; Lev. 19:4; 26:30; Num. 25:2; 33:52; Deut. 5:8; 29:16; 32:17.21). ${ }^{40}$ As the Pliny’s letter to Tra-

39 See Ameling, Der Kleinasiatische Kaiserkult und die Öffentlichkeit, 15-30.

40 See Sommer, "Bund Tora und eklektizistische Identitätsbildung," 315. 
jan shows, it was incompatible with normal, everyday life in Asia Minor. ${ }^{41}$ This document clearly demonstrates that Christians were not persecuted because of their religious beliefs. They only ran the risk of being persecuted if they committed acts of provocation against the government or disturbed the public order by refusing not to acknowledge the Emperor as ruler in public.

Furthermore, in Revelation 21:8.27, John prophecies that cultic or sexual uncleanness will lead to punishment. The words he uses, $\beta \delta \varepsilon \lambda u ́ \sigma \sigma o \mu \alpha \mathrm{t}$ and $\beta \delta \varepsilon \dot{\lambda} \nu y \mu \alpha$, are specific terms of the cultic and dietary laws of Leviticus (Lev. 11:11.13.43; 18:30; 20:23.25; 26:11). It is likely that John used this language from the Torah in order to highlight his instructions not to eat meat that was sacrificed to foreign gods (Rev. 2:14.20). John criticised those of his addressees who participated in Greco-Roman cults or bought idol meat sold at the market by employing specific laws of the Torah.

\subsection{The Politics of Intertexts}

Although John did not write his book only to argue against Christian's participation in the Imperial Cult, his perspective on politics and society at large is negative and judgmental. The Babylon motif in Revelation 17-18 is a prime example of this. Revelation 17 describes a scenario in which the Great Whore of Babylon fornicates with the kings of the earth and seduces all nations. Revelation 18 takes up the same motif, but reveals it to be a symbol for a great city that is the home of evil forces. The chapter portrays God's judgment over Babylon in detail. Many scholars still see Babylon here as a figurative expression for Rome. However, Alkier convincingly argues that it instead symbolises political and economic injustice in general. It certainly stands for more than Rome or the imperial cult, although a first-century reader may well have associated the motif primarily with the Empire. ${ }^{42}$ In his Babylon passage, John combines allusions to the Babylonian oracles of Jeremiah with Ezekiel's vision showing God's judgment over Tyre and Sidon (Ezek. 28). But other passages with implicit political meanings (for instance, Rev. 6; 8; 16 and 19) also strongly rely on intertexts such as Exodus, Daniel, Isaiah, or Ezekiel. It is by no means an over-interpretation to call these text-text relationships political, because they have the potential to be read as such. I would go so far as to say that particularly in these passages, John created overlaps between the reception of scriptures and veiled allusions to his political environment. ${ }^{43}$ Although the Babylon passage

41 Plinius, Briefe, 10, ed. Kasten, 96-97

42 Alkier, "Schwerwiegende Differenzen."

43 Sommer, "Die literarische Konzeption von räumlicher und zeitlicher Wahrnehmung in der Johannesoffenbarung." 
in Revelation $17-18$ is full of intertexts, scholars like Robyn Whitaker, ${ }^{44}$ Thomas Witulski ${ }^{45}$ and Annette Weissenrieder ${ }^{46}$ have convincingly argued that it shares many motifs with contemporary political discourses of the Empire. ${ }^{47}$

\section{Conclusion}

John clearly and intentionally chose specific textual authorities to suit his many different audiences. The notion of a reader steeped in the Hebrew scriptures, still current amongst some scholars, ignores essential aspects of the text. With his intertexts, John tried to reach people who were in contact with synagogues, but also people who were fully integrated into Greco-Roman society. His intertexts also had a political dimension and were remarkably Jewish in character. John did not only use prophetic texts to portray his notion of God. He also alluded to the Decalogue in order to describe his idea of ethics and to prohibit idolatry. He even went so far as to employ the language of the cultic purity laws of Leviticus in order to emphasise that the heavenly cult is rooted in the Torah. In my eyes, for John the Torah was more than just an ethical description of God's will. I think he still read the Torah as an instruction of how to worship God correctly.

Revelation's text-text relationships also reveal conflicts between John and other groups of Christians. It might be that John argued against teachings similar to the pseudo-Pauline writings that attributed little importance to the laws of the Torah.

Simply put, John's specific choice of intertexts created its own form of Christian identity that differed significantly from those proposed in other late first- or early second-century Jewish or Christian texts. Although texts like 2 Baruch, 4 Ezra, or the Apocalypse of Abraham utilised Israel's traditions intensely, John's intertextual way of claiming authority or creating ethics and theology was very different and thus stood in contrast to authors like Ignatius or Polycarp, who presented Christological ideas with little reference to Israel's traditions.

44 Whitaker sees similarities between Rev 18 and imperial funeral traditions. Whitaker, "Falling Stars and Rising Smoke.”

45 Witulski believes in allusion to the Judea-Capta-coinage (66-70 BCE/132-135 BCE). Witulski, Die Johannesoffenbarung und Kaiser Hadrian.

46 Weissenrieder compares depictions of Dea Roma with Rev. 17. Weissenrieder, "Bilder zum Sehen - Bilder zum Hören.”

47 Such discursive overlapping of motifs takes place in nearly every part of the book. See the commentary of Aune, Revelation. 


\section{Bibliography}

\section{Abbreviations}

$\begin{array}{ll}\text { BEThL } & \text { Bibliotheca Ephemeridum Theologicarum Lovanensium } \\ \text { BThSt } & \text { Biblisch-Theologische Studien } \\ \text { BZNW } & \text { Zeitschrift für die neutestamentliche Wissenschaft und die Kunde der älteren } \\ & \text { Kirche } \\ \text { CBET } & \text { Contributions to Biblical Exegesis and Theology } \\ \text { DCLS } & \text { Deuterocannonical and Cognate Literature Studies } \\ \text { EHS.T } & \text { Europäische Hochschulschriften: Theologie } \\ \text { FRLANT } & \text { Forschungen zur Religion und Literatur des Alten und Neuen Testaments } \\ \text { JSNT.S } & \text { Journal for the Study of the New Testament. Supplement Series } \\ \text { NTOA/STUNT } & \text { Novum Testamentum et Orbis Antiquus/Studien zur Umwelt des Neuen Testaments } \\ \text { NTS } & \text { New Testament Studies, 1955- } \\ \text { SBAB } & \text { Stuttgarter Biblische Aufsatzbände } \\ \text { SBB } & \text { Stuttgarter Biblische Beiträge } \\ \text { SBS } & \text { Stuttgarter Bibelstudien } \\ \text { S.JSJ } & \text { Supplements to the Journal for the Study of Judaism } \\ \text { TANZ } & \text { Texte und Arbeiten zum neutestamentlichen Zeitalter } \\ \text { ThKNT } & \text { Theologischer Kommentar zum Neuen Testament } \\ \text { WBC } & \text { Word Biblical Commentary } \\ \text { WUNT } & \text { Wissenschaftliche Untersuchung zum Neuen Testament } \\ \text { ZThK } & \text { Zeitschrift für Theologie und Kirche, Mohr Siebeck, 1891- } \\ & \end{array}$

\section{Primary Sources}

Plinius, Briefe. Lateinisch-Deutsch. Edited by Helmut Kasten, Zürich: Artemis \& Winkler, 1990.

\section{Secondary Literature}

Alkier, Stefan. "Schwerwiegende Differenzen. Vernachlässigte Antagonismen in der Johannesapokalypse.” In Diversität - Differenz - Dialogizität. Religion in pluralen Kontexten, edited by Christian Wiese, Stefan Alkier, Michael Schneider, 247-289. Berlin, New York: De Gruyter, 2017.

Ameling, Walter. “Der kleinasiatische Kaiserkult und die Öffentlichkeit. Überlegungen zur Umwelt der Apokalypse." In Kaiserkult, Wirtschaft und spectacula. Zum politischen und gesellschaftlichen Umfeld der Offenbarung, edited by Martin Ebner and Elisabeth Esch-Wermeling, 15-54. NTOA/STUNT 72. Göttingen: Vandenhoek \& Ruprecht, 2011.

Aune, David E. Revelation 1-5. Vol. 52, Word Biblical Commentary. Nashville: Thomas Nelson, 19971998.

Beale, Gregory K. The Use of Daniel in Jewish Apocalyptic Literature and in Revelation of St. John. Lanham, New York, London: University Press of America, 1984. 
Caird, George B. A Commentary on the Revelation of St. John Divine. New York, Evanston: Adam \& Charles Black, 1966.

Casey, Jay S. "Exodus Typology in the Book of Revelation." PhD dissertation, The Southern Baptist Theological Seminary, 1981 (unpublished).

Dochhorn, Jan. Schriftgelehrte Prophetie. Der eschatologische Teufelsfall in Apc Joh 12 und seine Bedeutung für das Verständnis der Johannesoffenbarung. WUNT I 268. Tübingen: Mohr Siebeck, 2010.

Fekkes, Jan. Isaiah and Prophetic Traditions in the Book of Revelation: Visionary Antecedents and their Development. JSNT.S 93. Sheffield: Sheffield Academic Press, 1994.

Frey, Jörg. “Die Bildersprache der Johannesapokalypse." ZThK 98 (2001): 161-185.

Frey, Jörg. "Autorfiktion und Gegnerbild im Judasbrief und im Zweiten Petrusbrief." In Pseudepigraphie und Verfasserfiktion in frühchristlichen Briefen. Pseudepigraphy and Author Fiction in Early Christian Letters, edited by Jörg Frey, Jens Herzer, Martina Jansen and Clare K. Rothschild, 683-732. WUNT 246. Tübingen: Mohr Siebeck, 2009.

Giesen, Heinz. “Das Römische Reich im Spiegel der Johannes-Apokalypse.” In Studien zur Johannesapokalypse, edited by Heinz Giesen, 100-213. SBAB 29. Stuttgart: Katholisches Bibelwerk, 2000.

Giesen, Heinz. "Lasterkataloge und Kaiserkult in der Offenbarung des Johannes." In Studien zur Johannesoffenbarung und ihrer Auslegung, edited by Friedrich W. Horn and Michael Wolter, 210-231. Festschrift für Otto Böcher zum 70. Geburtstag. Neukirchen-Vluyn: Neukirchener Verlag, 2005.

Giesen, Heinz. "Christlicher Glaube in Anfechtung und Bewährung. Zur zeit- und religionsgeschichtlichen Situation der kleinasiatischen Gemeinden im Spiegel der Johannesoffenbarung." In Mächtige Bilder. Zeit- und Wirkungsgeschichte der Johannesoffenbarung, edited by Bernhardt Heininger, 9-38. SBS 225. Stuttgart: Katholisches Bibelwerk, 2011.

Hays, Richard. "Faithful Witness, Alpha and Omega. The Identity of Jesus in the Apocalypse of John." In Revelations and the Politics of Apocalyptic Interpretation, edited by Richard Hays and Stefan Alkier, 68-83. Waco/Texas: Baylor University Press, 2015.

Hieke, Thomas. "Der Seher Johannes als neuer Ezechiel. Die Offenbarung des Johannes vom Ezechielbuch her gelesen." In Das Ezechielbuch in der Johannesoffenbarung, edited by Dieter Sänger, 1-30. BThSt 76. Neukirchen-Vluyn: Neukirchener Verlag, 2004.

Hieke, Thomas. "Die literarische und theologische Funktion des Alten Testaments in der Johannesoffenbarung." In Poetik und Intertextualität der Johannesoffenbarung, edited by Stefan Alkier, Thomas Hieke and Tobias Nicklas in Zusammenarbeit mit Michael Sommer, 271-290. WUNT I 346. Tübingen: Mohr Siebeck, 2015.

Karrer, Martin. "Die Apokalypse und das Aposteldekret.” In Beiträge zur urchristlichen Theologiegeschichte, edited by Wolfgang Kraus, 429-452. BZNW 163. Berlin, New York: De Gruyter, 2009.

Kelhofer, James A. Persecution, Persuasion and Power. Readiness to Withstand Hardship as a Corroboration of Legitimacy in the New Testament. WUNT 270. Tübingen: Mohr Siebeck, 2010.

Klauck, Hans-Joseph. "Das Sendschreiben nach Pergamon und der Kaiserkult in der Johannesoffenbarung." Biblica 73 (1992): 153-182.

Kowalski, Beate. Die Rezeption des Propheten Ezechiel in der Offenbarung des Johannes. SBB 52. Stuttgart: Katholisches Bibelwerk, 2004.

Lichtenberger, Hermann. Die Apokalypse. ThKNT 23. Stuttgart: Kohlhammer Verlag, 2013.

Lieu, Judith. Neither Jew nor Greek. Constructing Early Christianity. Studies of the New Testament and its World Series. Edinburgh: T \& T Clark, 2002.

Moyise, Steve. The Old Testament in the Book of Revelation. The Library of New Testament Studies. JSNT.S 115. Sheffield: Sheffield Academic Press, 1995. 
Moyise, Steve. "The Psalms in the Book of Revelation." In The Psalms in the New Testament, edited by Steve Moyise and Maarten J.J. Menken, 231-246. London, New York: T\&T Clark International, 2004.

Müller, Ulrich B. "Die Tiefen des Satans erkennen... Überlegungen zur theologiegeschichtlichen Einordnung der Gegner in der Offenbarung des Johannes." In Beiträge zur urchristlichen Theologiegeschichte, edited by Wolfgang Kraus, 465-478. BZNW 163. Berlin, New York: De Gruyter, 2009.

Müller-Frieberg, Rita. "Paulusrezeption in der Offenbarung des Johannes? Auf der Suche nach dem Erbe des Apostels im letzten Buch des biblischen Kanons.” NTS 55 (2009): 83-109.

Nicklas, Tobias. "Diesseits aus der Sicht des Jenseits: Die Sendschreiben der Offenbarung des Johannes (Offb 2-3)." In Other Worlds and their Relation to this World. Early Jewish and Ancient Christian Traditions, edited by Tobias Nicklas, Joseph Verheyden, Erik Eynikel and Florentino García Martínez, 247-279. S.JSJ 143. Leiden-Boston: Brill, 2010.

Nicklas, Tobias. Jews and Christians? Second Century 'Christian' Perspectives on the 'Parting of the Ways'. Annual Deichmann Lectures 2013. Tübingen: Mohr Siebeck, 2014.

Ruiz, Jean-Pierre. Ezekiel in the Apocalypse. The Transformation of Prophetic Language in Revelation 16:17-19:10. EHS.T 23/376. Frankfurt: Peter Lang, 1989.

Schüssler-Fiorenza, Elisabeth. The Book of Revelation. Justice and Judgment. Philadelphia, PA: Fortress Press, 1985.

Sommer, Michael. "Die literarische Konzeption von räumlicher und zeitlicher Wahrnehmung in der Johannesoffenbarung." Biblica 96 (2015): 565-585.

Sommer, Michael. "Der Tag der Plagen" - Studien zur Verbindung der Rezeption von Ex 7-11 in den Posaunen- und Schalenvisionen der Johannesoffenbarung und der Tag des Herrn Tradition. WUNT II 387. Tübingen: Mohr Siebeck, 2015.

Sommer, Michael. "Bund, Tora und eklektizistische Identitätsbildung: Zur Rolle von Ex 19-20 in der Apokalypse des 'Christusanhängers' Johannes.” In Exodus. Rezeptionen in deuterokanonischer und frühjüdischer Literatur, edited by Judith Gärtner and Barbara Schmitz, 299-319. DCLS 32. Berlin, New York: De Gruyter, 2016.

Sommer, Michael. "Die Nikolaiten und die Gegnerfiktion in der Offenbarung des Johannes - eine Annäherung an einige hermeneutische Probleme der Apokalypselektüre." In Shadowy Characters and Fragmentary Evidence: The Search for Early Christian Groups and Movements, edited by Joseph Verheyden, Tobias Nicklas and Elisabeth Hernitscheck, WUNT I, 49-67. Tübingen: Mohr Siebeck, 2017.

Ulland, Harald. Die Vision als Radikalisierung der Wirklichkeit in der Apokalypse des Johannes. Das Verhältnis der sieben Sendschreiben zu Apokalypse 12-13. TANZ 21. Tübingen, Basel: Francke, 1997.

Vanhoye, Albert. “L'utilisation du Livre d'Ezechiel dans L'Apocalypse.” Biblica 43 (1962): 436-476.

Viljoen, Francois P. "Faithful Christian Living amidst Scoffers of the Judgment Day. Ethics and Ethos in Jude and 2 Peter." In Identity, Ethics, and Ethos in the New Testament, edited by Jan G. van der Watt, 11-533. BZNW 141. Berlin, New York: De Gruyter, 2006.

Vogelgesang, Jeffrey M. "The Interpretation of Ezekiel in the Book of Revelation.” PhD Dissertation, Cambridge/Mass.: Harvard University, 1985.

Vos, Louis A. The Synoptic Traditions in the Apocalypse. Kampen: J.H. Kok, 1965.

Weissenrieder, Annette. "Bilder zum Sehen - Bilder zum Hören? Über die Grenzen von visuellem Bild und Sprache als Ekphrasis in Apk 17." In Poetik und Intertextualität der Johannesoffenbarung, edited by Stefan Alkier, Thomas Hieke and Tobias Nicklas in Zusammenarbeit mit Michael Sommer, 241-270. WUNT I 346. Tübingen: Mohr Siebeck, 2015. 
Whitaker, Robyn J. "Falling Stars and Rising Smoke. Imperial Apotheosis and Idolatry in Revelation." In Imagery in the Book of Revelation, edited by Michael Labahn and Outi Lehtipuu, 199218. CBET 60. Leuven: Peeters, 2011.

Witetscheck, Stephan. "Der Lieblingspsalm des Sehers: die Verwendung von Ps 2 in der Johannesapokalypse." In The Septuagint and Messianism: Colloquium Biblicum Lovaniense LIII, July 27-29, 2004, edited by Michael A. Knibb, 487-502. BEThL 195. Leuven: Leuven University Press \& Peeters, 2006.

Witulski, Thomas. Die Johannesoffenbarung und Kaiser Hadrian. Studien zur Datierung der neutestamentlichen Apokalypse. FRLANT 221. Göttingen: Vandenhoek \& Ruprecht, 2007.

Yarbro Collins, Adela. "The Use of Scripture in Revelation." Presidential Address at the Colloquium Biblicum Lovaniense LXV (July, 23-25, 2015): New Perspectives on the Book of Revelation.

Yarbro Collins, Adela. "Rewritten Prophets: The Use of older Scriptures in Revelation." In Poetik und Intertextualität der Johannesoffenbarung, edited by Stefan Alkier, Thomas Hieke and Tobias Nicklas in Zusammenarbeit mit Michael Sommer, 291-299. WUNT I 346. Tübingen: Mohr Siebeck, 2015. 